CZASOPISMO INŻYNIERII LĄDOWEJ, ŚRODOWISKA I ARCHITEKTURY JOURNAL OF CIVIL ENGINEERING, ENVIRONMENT AND ARCHITECTURE

JCEEA, t. XXXIII, z. 63 (3/16), lipiec-wrzesień 2016, s. 95-104

\author{
Halina GARBALIŃSKA ${ }^{1}$ \\ Jarosław STRZAŁKOWSKI ${ }^{2}$
}

\title{
KRUSZYWO JAKO CZYNNIK KSZTAŁTUJĄCY PARAMETRY CIEPLNE BETONÓW O NIEMODYFIKOWANEJ MATRYCY CEMENTOWEJ
}

\begin{abstract}
W niniejszej pracy poddano analizie wpływ użytego kruszywa na właściwości termiczne kompozytów betonowych o niemodyfikowanej matrycy cementowej. Przetestowano trzy rodzaje kruszyw: kruszywo kamienne o dużej szczelności oraz dwa kruszywa lekkie: keramzytowe oraz popiołoporytowe. Przeprowadzono rtęciowe badania porozymetryczne samych kruszyw, jak również betonów na ich bazie. Wykonane mieszanki betonowe charakteryzowały się niemodyfikowaną matrycą cementową, dzięki czemu możliwe było porównanie zróżnicowanych właściwości betonów wynikających z wariantowo dobranego kruszywa gruboziarnistego.

W pracy przygotowano dwa rodzaje próbek: płytkowe do badań cieplnych oraz sześcienne potrzebne do przeprowadzenia testów wytrzymałości betonu na ściskanie. Próbki przez pierwsze 28 dni przechowywano w komorze klimatycznej w wysokiej wilgotności, następnie próbki umieszczono w powietrzno-suchych warunkach laboratoryjnych. Parametry termiczne betonów testowano przez pierwszy rok dojrzewania w zadanych przedziałach czasu. Podobnie wykonywano badania wytrzymałości na ściskanie po 7, 14, 28 dniach oraz po 3, 6 i 12 miesiącach dojrzewania betonu. W publikacji wykazano wyraźną korelację między porowatością kruszywa a przewodnością cieplną i ciepłem właściwym betonów. Struktura kruszywa miała również niebagatelny wpływ na tempo wysychania betonów. Przedstawiono także zależność między porowatością kruszyw a wytrzymałością betonu na ściskanie. W pracy pokazano także zdjęcia SEM przekrojów przez badane betony.
\end{abstract}

Słowa kluczowe: keramzyt, kruszywo popiołoporytowe, kruszywo kamienne przewodność cieplna, pojemność cieplna, porozymetria rtęciowa, badania SEM

\footnotetext{
${ }^{1}$ Autor do korespondencji / corresponding author: Halina Garbalińska, Zachodniopomorski Uniwersytet Technologiczny w Szczecinie, Katedra Fizyki Budowli i Materiałów Budowlanych, al. Piastów 50, 70-311 Szczecin, tel. 9144942 91; Halina.Garbalinska@zut.edu.pl

2 Jarosław Strzałkowski, Zachodniopomorski Uniwersytet Technologiczny w Szczecinie, Katedra Fizyki Budowli i Materiałów Budowlanych, al. Piastów 50, 70-311 Szczecin, tel. 9144943 41; jstrzalkowski@zut.edu.pl
} 


\section{Wprowadzenie}

Udział kruszywa w objętości betonu przekracza często $50 \%$, dlatego też jest jednym z najważniejszych czynników kształtujących jego właściwości. Ma ono dominujący wpływ na podstawowe parametry betonu takie jak wytrzymałość na ściskanie i rozciąganie, nasiąkliwość, jak również jego właściwości cieplne. Poprzez dobór odpowiedniego kruszywa możliwe jest zatem bezpośrednie oddziaływanie na wynikowe właściwości betonu. Obecnie dysponujemy szeroką gamą kruszyw [2], [3]: począwszy od zwykłego kruszywa kamiennego, przez lekkie kruszywa takie jak keramzyt czy popiołoporyt nadające betonowi właściwości izolacyjne, aż po ciężkie kruszywa bazaltowe i magnetytowe istotnie wpływające na wytrzymałość i odporność betonu na promieniowanie.

Kształtowanie właściwości betonu za pośrednictwem różnego rodzaju kruszyw jest tematem często podejmowanym w literaturze przedmiotu. Na przykład w [6] Ślosarczyk i in. przeanalizowali wpływ dodania tlenku glinu na właściwości mechaniczne betonu na bazie kruszywa lekkiego. Wykazali, że dodatek elektrokorundu poprawia zagęszczenie struktury zaczynu, zwiększając tym samym wytrzymałość na ściskanie i odporność na ścieranie. Również użycie dodatku żużla paleniskowego, traktowanego jako zamiennik grubego kruszywa kamiennego wpływa na właściwości mechaniczne i mikrostrukturalne betonu [5].

Porowata struktura kruszyw popiołoporytowych może być m.in. wykorzystana w konstrukcjach wymagających podwyższonej mrozoodporności. W [1] omówiono zagadnienie mrozoodporności konstrukcyjnych betonów lekkich ze szczególnym uwzględnieniem wpływu jego wstępnej wilgotności. Uzyskane rezultaty wskazują, że podwyższoną mrozoodporność można zapewnić stosując lekkie kruszywo o niskim zawilgoceniu wstępnym (patrz [1]).

Kruszywo wywiera również duży wpływ na właściwości zapraw. Badania przedstawione w [4] wykazały wyraźne zróżnicowanie właściwości zarówno mechanicznych jak i termoizolacyjnych w zależności od użytego kruszywa drobnoziarnistego.

W niniejszym artykule podjęto próbę oceny wpływu specyficznej struktury porowatości różnych rodzajów kruszyw na właściwości stwardniałego betonu, ze szczególnym uwzględnieniem parametrów termicznych oraz wytrzymałości na ściskanie.

\section{Testowane materiały}

W pracy przetestowano trzy rodzaje kruszyw: zwykłe kruszywo kamienne bazowe (B) o niskiej nasiąkliwości oraz dwa kruszywa lekkie - keramzyt $(\mathrm{K})$ i popiołoporyt $(\mathrm{P})$.

Podstawowe właściwości testowanych kruszyw przedstawiono w tabeli $\mathrm{nr}$ 1. Otrzymane wartości testowano dla tego samego zakresu frakcji z przedziału od 4 do $8 \mathrm{~mm}$. 
Tabela 1. Właściwości fizyczne badanych kruszyw

Table 1. Physical properties of the tested aggregates

\begin{tabular}{|c|c|c|c|c|c|}
\hline \multirow{2}{*}{$\begin{array}{l}\text { Rodzaj } \\
\text { kruszywa }\end{array}$} & \multirow{2}{*}{$\begin{array}{c}\text { Nasią- } \\
\text { kliwość } \\
\text { [\%] }\end{array}$} & \multicolumn{2}{|c|}{$\begin{array}{c}\text { Gęstośćć objętościowa } \\
{\left[\mathrm{g} / \mathrm{cm}^{3}\right]}\end{array}$} & \multirow{2}{*}{$\begin{array}{c}\text { Gęstość wła- } \\
\text { ściwa (poro- } \\
\text { zymetryczna) } \\
{\left[\mathrm{g} / \mathrm{cm}^{3}\right]}\end{array}$} & \multirow{2}{*}{ 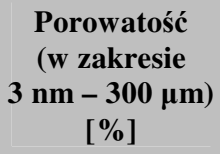 } \\
\hline & & $\begin{array}{l}\text { hydrosta- } \\
\text { tyczna }\end{array}$ & $\begin{array}{l}\text { porozyme- } \\
\text { tryczna }\end{array}$ & & \\
\hline Kamienne - B & 1,64 & 2,50 & 2,55 & 2,61 & 2,20 \\
\hline Keramzyt - K & 28,29 & 0,56 & 0,55 & 2,27 & 75,94 \\
\hline Popiołoporyt - P & 22,49 & 1,31 & 1,37 & 2,55 & 46,30 \\
\hline
\end{tabular}

Na bazie tych kruszyw wykonano trzy mieszanki betonowe, których skład recepturowy podano $\mathrm{w}$ tabeli $\mathrm{nr} 2$. Z uwagi na wysoką nasiąkliwość kruszyw lekkich postanowiono testować receptury wprowadzając je w stanie pełnego nasycenia wodą - tak, aby możliwe było porównanie otrzymanych wyników z betonem referencyjnym na bazie kruszywa kamiennego.

Tabela 2. Receptury testowanych betonów w przeliczeniu na $1 \mathrm{~m}^{3}$ oraz ich podst. właściwości Table 2. The recipes of the tested concretes calculated for $1 \mathrm{~m}^{3}$ and their basic properties

\begin{tabular}{|c|c|c|c|c|c|c|c|}
\hline \multirow{2}{*}{ Typ: } & \multirow{2}{*}{$\begin{array}{c}\text { Kruszywo } \\
{\left[\mathrm{kg} / \mathrm{m}^{3}\right]}\end{array}$} & \multirow{2}{*}{$\begin{array}{c}\text { Piasek } \\
{\left[\mathrm{kg} / \mathrm{m}^{3}\right]}\end{array}$} & \multirow{2}{*}{$\begin{array}{l}\text { Cement } \\
{\left[\mathrm{kg} / \mathrm{m}^{3}\right]}\end{array}$} & \multirow{2}{*}{$\begin{array}{c}\text { Woda } \\
{\left[\mathrm{kg} / \mathrm{m}^{3}\right]}\end{array}$} & \multicolumn{2}{|c|}{$\begin{array}{c}\text { Gęstość objętościowa } \\
{\left[\mathrm{g} / \mathrm{cm}^{3}\right]}\end{array}$} & \multirow{2}{*}{$\begin{array}{c}\text { Porowa- } \\
\text { tość } \\
{[\%]}\end{array}$} \\
\hline & & & & & $\begin{array}{l}\text { bezpo- } \\
\text { średnia }\end{array}$ & $\begin{array}{l}\text { porozyme- } \\
\text { tryczna }\end{array}$ & \\
\hline $\mathrm{B} / \mathrm{B}$ & 1312,73 & 469,53 & 391,27 & 215,20 & 2,27 & 2,31 & 10,90 \\
\hline $\mathrm{B} / \mathrm{K}$ & 338,38 & 486,87 & 405,73 & 223,15 & 1,18 & 1,20 & 47,80 \\
\hline $\mathrm{B} / \mathrm{P}$ & 844,55 & 471,10 & 392,58 & 215,92 & 1,52 & 1,61 & 35,43 \\
\hline
\end{tabular}

W mieszankach wykorzystano kruszywa grube frakcji 4-8 mm. Wszystkie receptury charakteryzowały się stałym współczynnikiem w/c równym 0,55. Przyjęto także stałą proporcję ilości piasku do cementu wynoszącą 1,2. W żadnej mieszance nie zastosowano jakichkolwiek domieszek. Niewielkie rozbieżności w ilości poszczególnych składników zaprawy wynikają z przeliczenia składników do rzeczywistej uzyskanej objętości projektowanego betonu. W przypadku każdego $\mathrm{z}$ testowanych betonów wykonano po sześć próbek płytkowych o wymiarach $14 \times 16 \times 4 \mathrm{~cm}$, niezbędnych do badania parametrów cieplnych oraz po 30 próbek sześciennych $10 \times 10 \times 10 \mathrm{~cm}$ do testów wytrzymałościowych. Próbki przez pierwsze 28 dni dojrzewania przechowywano w komorze klimatycznej o wilgotności powyżej $90 \%$, następnie składowano je w laboratoryjnych warunkach powietrzno-suchych. 


\section{Wyniki badań}

W pierwszej kolejności wykonano badania porozymetryczne ziaren testowanych kruszyw. Dobór próbki badawczej polegał na wyselekcjonowaniu po cztery ziarna kruszywa o średnicach odpowiednio 4, 5, 6 oraz $8 \mathrm{~mm}$. Wykresy logarytmiczno-różniczkowe rozkładu porów dla poszczególnych kruszyw przedstawiono na rys. 1 . W celu weryfikacji otrzymanych wyników doświadczenie przeprowadzono dwukrotnie dla wszystkich rodzajów kruszyw.

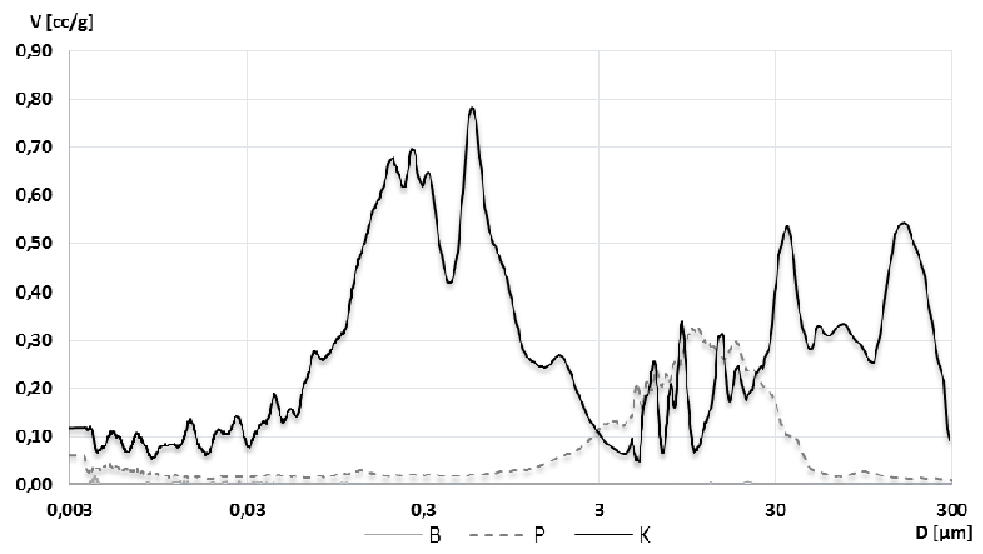

Rys. 1. Wykres logarytmiczno-różniczkowy rozkładu porów w testowanych kruszywach

Fig. 1. Log-differential graph distribution of air voids in the tested aggregates

Najwyższe rozkłady porów w strukturze kruszyw zaobserwowano dla keramzytu. Wyraźne są tutaj dwa dominujące obszary makroporów: od 0,05 do $3 \mu \mathrm{m}$ (z ekstremami przy średnicach 0,27 oraz $0,60 \mu \mathrm{m}$ ) oraz od 30 do $270 \mu \mathrm{m}$ (z ekstremami przy średnicach 36 oraz $168 \mu \mathrm{m}$ ). Kruszywo popiołoporytowe $\mathrm{z}$ kolei posiada jeden dominujący obszar porów z przedziału od ok. 3 do $30 \mu \mathrm{m}$. Badanie użytego kruszywa kamiennego nie wykazało w cały ocenianym zakresie wyraźnych obszarów porowatej struktury, dzięki czemu doskonale nadaje się ono do wykorzystania jako kruszywo referencyjne o wysokiej szczelności. Tabela 3 zawiera podstawową charakterystykę porowatości trzech analizowanych kruszyw.

Tabela 3. Charakterystyka porowatości badanych kruszyw

Table 3 . The porosity characteristics of the tested aggregates

\begin{tabular}{|c|c|c|c|}
\hline Charakterystyka & Keramzyt K & Popiołoporyt P & Kamienne B \\
\hline Całkowita powierzchnia właściwa $\left[\mathrm{m}^{2} / \mathrm{g}\right]$ & 54,253 & 13,234 & 0,902 \\
\hline Krętność porów [-] & 1,350 & 1,731 & 2,217 \\
\hline Przenikliwość $\left[\mathrm{nm}^{2}\right]$ & 0,026 & 0,014 & 0,001 \\
\hline Średnia objętość porów [cc/g] & 1,202 & 0,307 & 0,007 \\
\hline Średnia powierzchnia właściwa $\left[\mathrm{m}^{2} / \mathrm{g}\right]$ & 8,471 & 0,493 & 0,085 \\
\hline
\end{tabular}


Rys. 2 przedstawia rozkład porów powietrznych dla betonów wykonanych ma bazie testowanych kruszyw. Z uwagi na wysoką szczelność kruszywa kamiennego zarejestrowane w próbkach $\mathrm{B} / \mathrm{B}$ pory $\mathrm{z}$ przedziału 0,03 do $0,3 \mu \mathrm{m}$ związane są $\mathrm{z}$ matrycą cementową. Podobny rozkład w tym samym obszarze zaobserwowano $\mathrm{w}$ przypadku próbek $\mathrm{B} / \mathrm{P}$, w których dodatkowo stwierdza się duży udział porów, lokujących się w przedziale od 3 do $30 \mu \mathrm{m}$, co dokładnie pokrywa się $\mathrm{z}$ wykresem rozkładu porów dla samego popiołoporytu. Jednoznacznie najbardziej rozbudowanym rozkładem porów charakteryzuje się beton $\mathrm{B} / \mathrm{K}$. Także $\mathrm{w}$ nim dominują pory $\mathrm{z}$ tych samych zakresów, jak w przypadku czystego keramzytu. Natomiast sama matryca cementowa wyraźnie zwiększa porowatość w zakresie najdrobniejszych porów, poniżej $30 \mathrm{~nm}$.

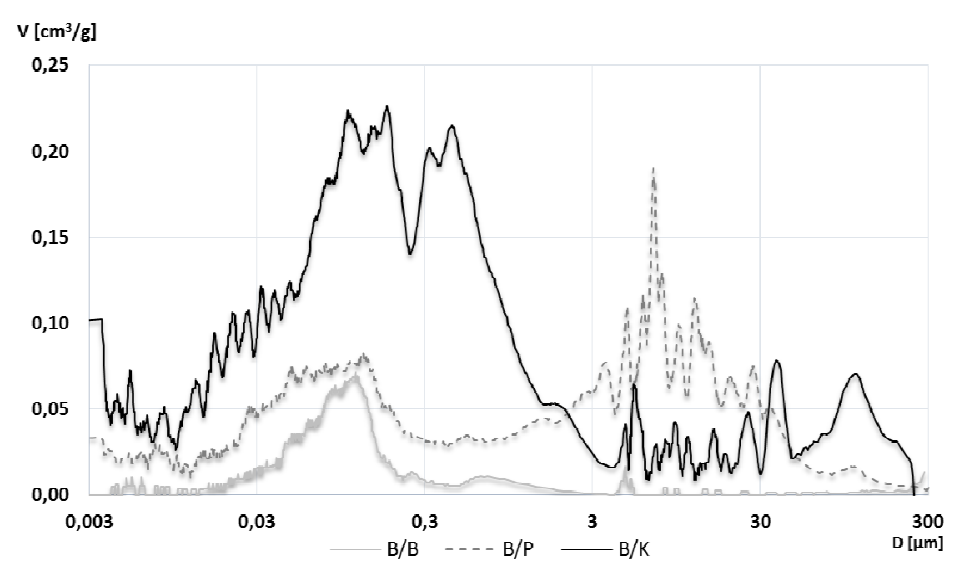

Rys. 2. Wykres logarytmiczno-różniczkowy rozkładu porów w testowanych betonach Fig. 2. Log-differential graph distribution of air voids in the tested concretes

Na rysunku 3 przedstawiono przekroje przez próbki poszczególnych betonów z porami wypełnionymi pastą cynkową.
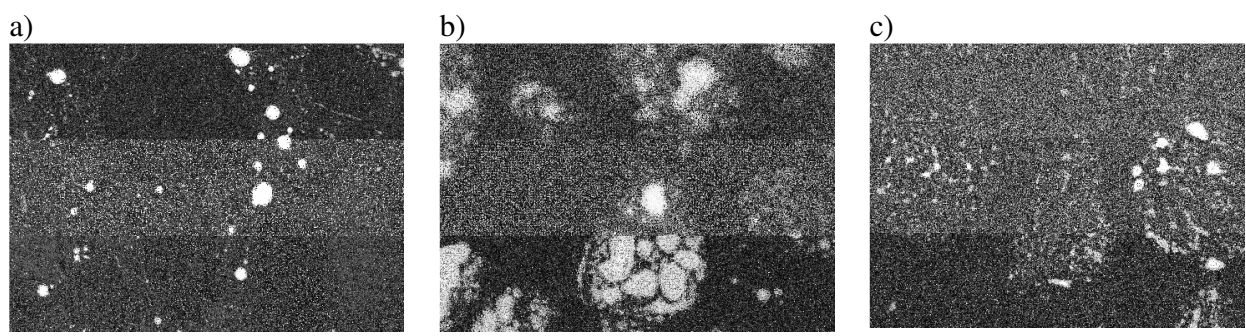

Rys. 3. Przekroje przez próbki betonów na bazie: a) kruszywa kamiennego b) keramzytu c) popiołoporytu (3-krotne powiększenie)

Fig. 3. Cross-sections of concrete samples based on: a) normal aggregate b) leca c) lytag (3-fold magnification) 
W zastosowanym powiększeniu na rysunku a) widoczne są wyłącznie pory znajdujące się w matrycy cementowej, kruszywo jest szczelne. Próbka b) na bazie karamzytu cechuje się wyraźną obecnością dużych porów otoczonych licznymi małymi porami. Natomiast próbka c) charakteryzuje się licznie występującymi niewielkimi porami o zbliżonej średnicy.

$\mathrm{Na}$ rysunku 4 przedstawiono wyniki badań współczynnika przewodzenia ciepła $\lambda$ testowanych próbek.

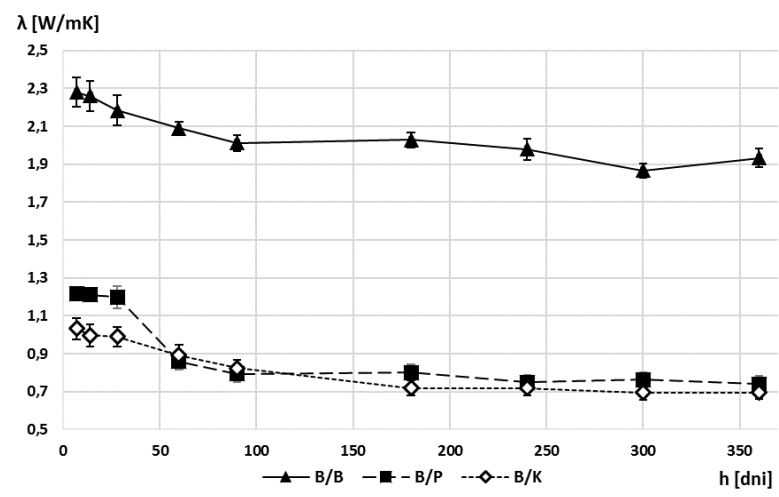

Rys. 4. Współczynniki przewodzenia $\lambda$ zarejestrowane w trakcie rocznego dojrzewania betonów

Fig. 4. Thermal conductivity coefficient $\lambda$ recorded during the first year of concretes curing

Wyraźnie widoczny jest wpływ porowatej struktury kruszywa na współczynnik $\lambda$. Betony na bazie kruszyw lekkich charakteryzowały się 2-krotnie niższą wartością tego parametru. Równocześnie różnice między ich współczynnikami $\lambda$ były niewielkie. Wynikałoby $\mathrm{z}$ tego, że na przewodzenie ciepła w bardziej znaczącym stopniu wpływają pory z przedziału 3 do $30 \mu \mathrm{m}$, aniżeli pory mniejsze od $3 \mu \mathrm{m}$, występujące w dużej ilości w keramzytobetonie.

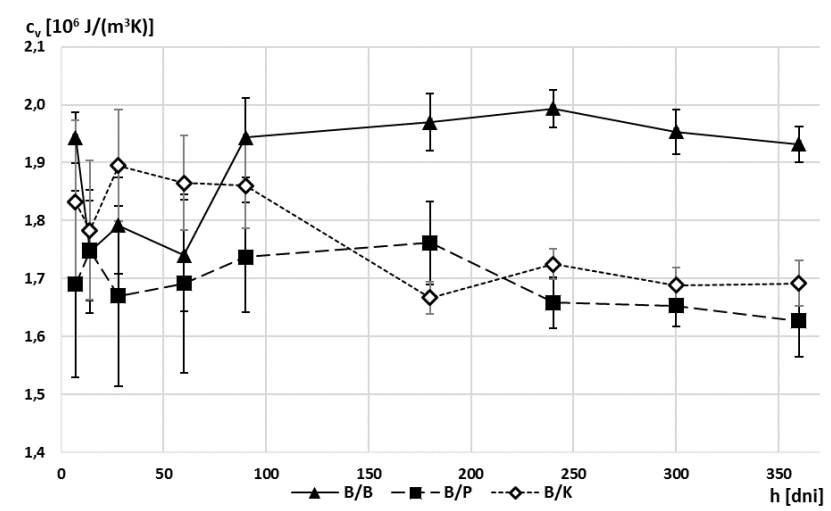

Rys. 5. Objętościowe ciepło właściwe $c_{v}$ rejestrowane w trakcie rocznego dojrzewania betonów

Fig. 5. Volumetric specific heat $c_{v}$ recorded during the first year of concretes curing 
Porowatość kruszywa wywiera także wpływ na ciepło właściwe badanych betonów, co ilustruje rysunek 5. Oddziaływanie jest bezdyskusyjne, ale bardzo zróżnicowane, w zależności od etapu, na jakim znajdują się dojrzewające i wysychające próbki. Po okresie roku ciepło właściwe zostało obniżone w stosunku do betonu zwykłego odpowiednio o 14,2 \% dla keramzytobetonu oraz o 18,8 \% dla popiołoporytobetonu. Należy także zwrócić uwagę, że największe wahania ciepła właściwego $c_{v} \mathrm{~W}$ okresie pierwszych 28 dni dojrzewania betonów występowały w próbkach betonu zwykłego i betonu na bazie keramzytu. Z kolei beton na bazie popiołoporytu charakteryzował się najbardziej równomiernym przebiegiem czasowej zmienności parametru $c_{v}$. Ma to związek przede wszystkim ze zróżnicowanym tempem procesu wysychania poszczególnych betonów (rys. 6).

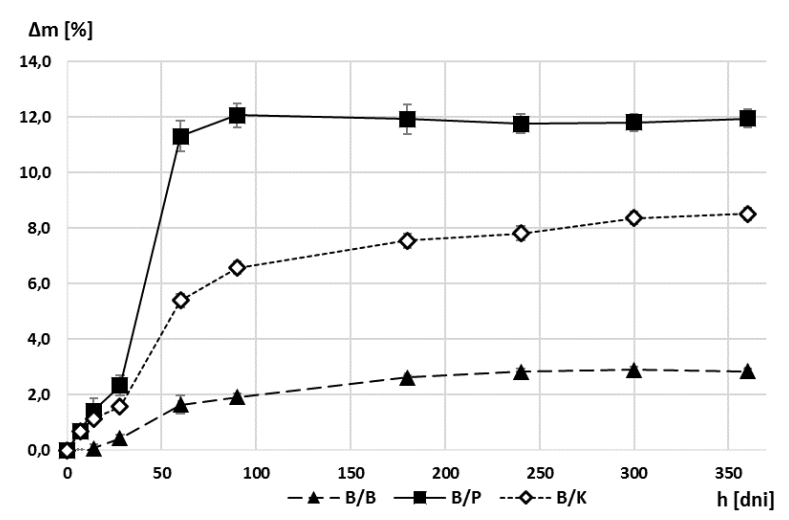

Rys. 6. Względny ubytek masy $\Delta m$ rejestrowany w trakcie pierwszego roku dojrzewania betonów

Fig. 6. Relative mass loss $\Delta m$ recorded during the first year of concretes curing

Porowatość kruszywa zróżnicowała istotnie wytrzymałość betonów na ściskanie (rys. 7). Po 28 dniach dojrzewania beton na bazie popiołoporytu miał o $42 \%$ niższą wytrzymałość średnią, a beton na bazie keramzytu o $66 \%$.

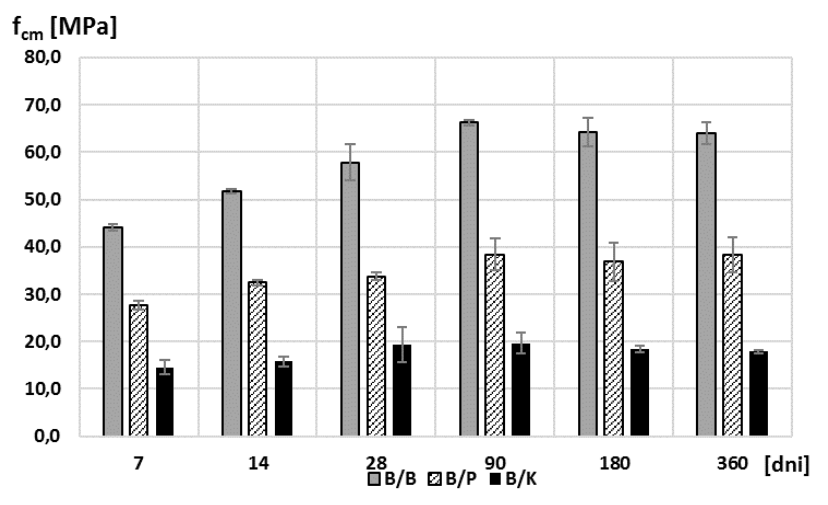

Rys. 7. Wytrzymałości na ściskanie $\mathrm{f}_{\mathrm{cm}} \mathrm{w}$ trakcie pierwszego roku dojrzewania betonu

Fig. 7. Compressive strength $\mathrm{f}_{\mathrm{cm}}$ recorded during the first year of concretes curing 
Na rysunkach 8-10 przedstawiono zdjęcia SEM przekrojów przez badane próbki betonów.

Pokazano po trzy zdjęcia ilustrujące wygląd przekroju próbek (rysunki a), strefę kontaktową między badanym kruszywem a matrycą cementową (rysunki b) oraz powiększenie struktury samego kruszywa (rysunki c). Próbki na bazie kruszywa kamiennego charakteryzują się jednorodną strukturą, bez wyraźnych porów powietrznych. Uwidacznia się natomiast strefa kontaktu między ziarnem

a)

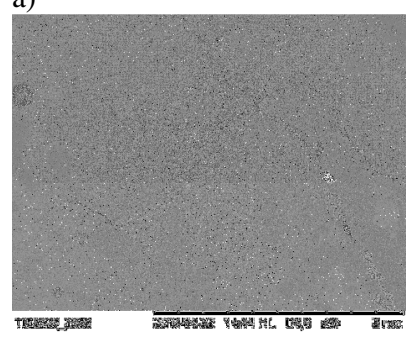

b)

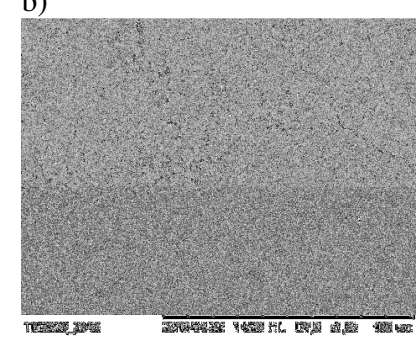

c)

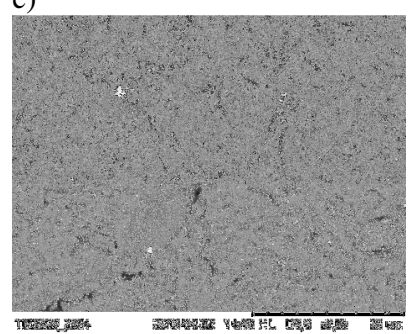

Rys. 8. Zdjęcia SEM betonu B $\backslash B$ : a) przekrój x50 b) strefa kontaktowa x1,0k c) kruszywo x2,0k

Fig. 8. SEM photos of $\mathrm{B} \backslash \mathrm{B}$ concrete: a) cross-section $\mathrm{x} 50 \mathrm{~b}$ ) contact zone $\mathrm{x} 1,0 \mathrm{k}$ c) aggregate $\mathrm{x} 2,0 \mathrm{k}$

a)

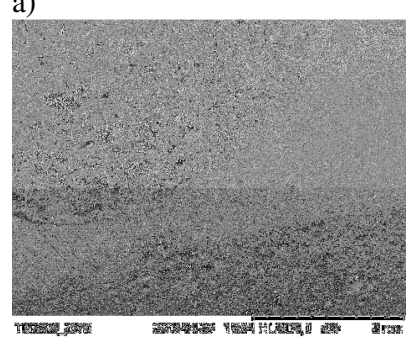

b)

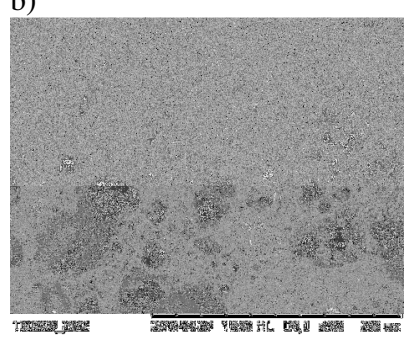

c)

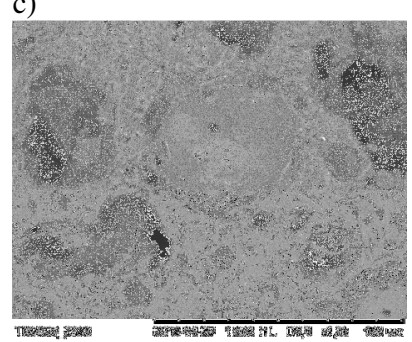

Rys. 9. Zdjęcia SEM betonu B\P: a) przekrój x30 b) strefa kontaktowa x500 c) kruszywo x1,0k

Fig. 9. SEM photos of B $(P$ concrete: a) cross-section $\times 30 \mathrm{~b}$ ) contact zone $\times 500 \mathrm{c}$ ) aggregate $\times 1,0 \mathrm{k}$

a)

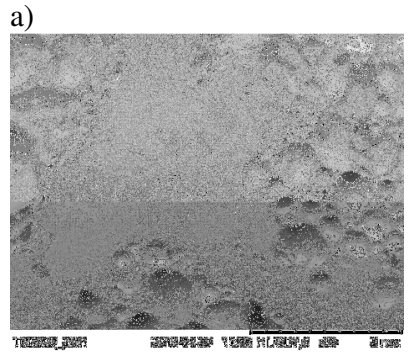

b)

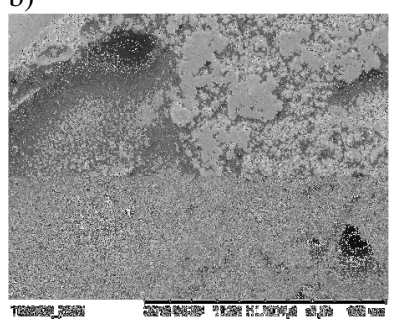

c)

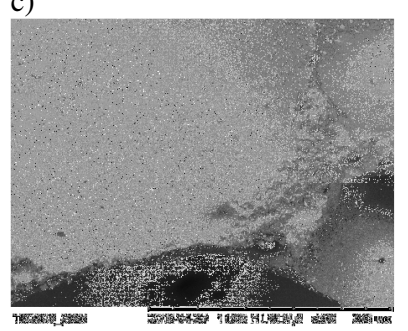

Rys. 10. Zdjęcia SEM betonu B \K: a) przekrój x30 b) strefa kontaktowa x1,0k c) kruszywo x500

Fig. 10. SEM photos of $\mathrm{B} \backslash \mathrm{K}$ concrete: a) cross-section $\mathrm{x} 30 \mathrm{~b}$ ) contact zone $\mathrm{x} 1,0 \mathrm{k}$ c) aggregate $\mathrm{x} 500$ 
a matrycą cementową. $\mathrm{W}$ próbkach $\mathrm{B} \backslash \mathrm{P}$ oraz $\mathrm{B} \backslash \mathrm{K}$ strefa kontaktu jest trudniejsza do dostrzeżenia. Zaczyn cementowy wyraźnie spenetrował otwarte pory w strukturze kruszyw lekkich, przez co trudniej odróżnić ziarno kruszywa od zaczynu.

Analizując samą strukturę kruszywa warto zwrócić uwagę na bardzo zwartą budowę kruszywa kamiennego, w którym nie obserwuje się występowania porów powietrznych, nawet przy dużym powiększeniu. W popiołoporycie natomiast wyraźnie widoczne są pory wielkości od 5 do $50 \mu \mathrm{m}$, co potwierdza wyniki z badań porozymetrii rtęciowej. Kruszywo keramzytowe natomiast zbudowane jest z bardzo dużych porów o średnicy przekraczającej znacznie $50 \mu$, ale sam spiek charakteryzuje się bardzo zwartą strukturą.

\section{Wnioski}

Analizowane kruszywa oraz wykonane na ich bazie betony charakteryzowały się bardzo dużą różnorodnością rozkładów porów powietrznych otrzymanych w rtęciowych badaniach porozymetrycznych. Odmienna struktura porowatości w odmienny sposób przełożyła się na podstawowe właściwości trzech grup testowanych betonów.

Wykazano, że użycie lekkich kruszyw może przyczynić się do znaczącego, bo ponad dwukrotnego obniżenia współczynnika przewodzenia ciepła $\lambda \mathrm{w}$ stosunku do betonów zwykłych. Wzajemne relacje uwidoczniono na rys. 4. Przykładowo po 360 dniach $\lambda_{B / B} / \lambda_{B / P}=2,61 ; \lambda_{B / B} / \lambda_{B / K}=2,78$. Wprawdzie także ciepło właściwe betonów lekkich zostało obniżone o $14 \div 18 \%$, ale należy podkreślić, że i tak otrzymane wartości $c_{v}$ były mimo wszystko dość wysokie, co pozwala zagwarantować przegrodom nie tylko dobrą izolacyjność cieplną, ale także stosunkowo dobrą akumulacyjność cieplną.

Jak należało się spodziewać kruszywa porowate znacznie osłabiły strukturę otrzymanych betonów (patrz rys. 7). Wytrzymałość na ściskanie po 28 dniach była zredukowana odpowiednio o $42 \% \mathrm{w}$ przypadku betonu na bazie popiołoporytu i o $66 \% \mathrm{w}$ przypadku betonu z keramzytem.

Porowatość kruszyw miała także wyraźny wpływ na zróżnicowane tempo wysychania poszczególnych betonów. Najszybciej proces przebiegał w betonie popiołoporytowym, a intensywne zmiany masy zachodziły w okresie około 3 miesięcy. Natomiast beton na bazie kruszywa kamiennego potrzebował pół roku do względnego ustabilizowania się masy badanych próbek, a w przypadku keramzytobetonu proces wysychania wygasał po upływie niemal rocznego okresu przechowywania próbek.

Badania lekkich kompozytów cementowych zrealizowano w ramach projektu badawczego nr 2014/13/N/ST8/00091 finansowanego przez Narodowe Centrum Nauki. 


\section{Literatura}

[1] L. Domagała, „Wpływ poziomu wstępnego nawilżenia kruszywa popiołoporytowego na mrozoodporność konstrukcyjnych betonów lekkich”, Przegląd Budowlany, tom 85, nr 5, pp. 18-21, 2014.

[2] W. Kozioł, A. Ciepliński, Ł. Machniak i A. Borcz, „Kruszywa w budownictwie. Cz. 1. Kruszywa naturalne”, Nowoczesne Budownictwo Inżynieryjne, tom 4, pp. 98-100, 2015.

[3] W. Kozioł, A. Ciepliński, Ł. Machniak i A. Borcz, „Kruszywa w budownictwie. Cz. 2. Kruszywa alternatywne", Nowoczesne Budownictwo Inżynieryjne, tom 5, pp. 3540, 2015.

[4] T. Rucińska, O. Chańko i A. Nowicka, ,Wpływ rodzaju cementu i kruszywa drobnoziarnistego na właściwości zapraw”, Materiały Budowlane, tom 12, pp. 80-82, 2015.

[5] P. Smarzewski i D. Barnat-Hunek, „Mechaniczne i mikrostrukturalne właściwości betonu wysokowartościowego z dodatkiem żużla paleniskowego", Izolacje, tom 20, nr 10, pp. 26-32, 2015.

[6] A. Ślosarczyk, T. Kantel, M. Walaszkowski i P. Zasada, „Physical and mechanical characterization of structural lightweight concrete with synthetic aloxite additive", Composites Theory and Practice, tom 15, nr 4, pp. 209-213, 2015.

\section{AGgREGATES AS THE SCHAPING FACTOR OF THERMAL PARAMETERS OF UNMODIFIED CEMENT MATRIX}

\section{S u m m a r y}

The paper presents the impact of aggregate on the thermal properties of concrete composites with non-modified cement matrix. Three types of aggregates were tested: normal aggregate of high tightness and two lightweight aggregates: leca and lytag. Mercury porosimetry tests were conducted on aggregates, as well as on the concretes made on their basis. Concrete mixes were characterized by an unmodified cement matrix which enabled to compare the diverse properties of concretes made with different aggregates.

Two types of samples were prepared in this study: plates samples for the thermal tests and cubic samples necessary for the examination of the compressive strength. The samples were kept in climate chamber for the first 28 days in high humidity atmosphere, subsequently were put in laboratory air-dry conditions. Thermal parameters of the concretes were tested during the first year of curing at specified time intervals. Likewise compressive strength tests were conducted after 7, 14, 28 days and 3, 6 and 12 months of concrete curing.

In the manuscript a high correlation was observed between the porosity of aggregates and the thermal conductivity and specific heat. The structure of the aggregate had a considerable impact on the pace of concretes drying. The association between the porosity and compressive strength was also presented. The paper also shows the SEM images of the cross-sections of the tested concretes.

Keywords: leca, lytag, normal aggregate, thermal conductivity, heat capacity, mercury porosimetry, SEM tests

DOI: $10.7862 / \mathrm{rb} .2016 .190$

Przestano do redakcji: $30.06 .2016 r$.

Przyjęto do druku: 30.11 .2016 r. 